\title{
The immunomodulator PSK induces in vitro cytotoxic activity in tumour cell lines via arrest of cell cycle and induction of apoptosis Eva Jiménez-Medina1 ${ }^{1}$ Enrique Berruguilla1, Irene Romero1 ${ }^{1}$, Ignacio Algarra², Antonia Collado ${ }^{3}$, Federico Garrido ${ }^{1}$ and Angel Garcia-Lora*1
}

\author{
Address: ${ }^{1}$ Servicio de Análisis Clínicos e Inmunologia, Hospital Universitario Virgen de las Nieves, Universidad de Granada, Av. de las Fuerzas \\ Armadas 2, 18014 Granada, Spain, ²Departamento de Ciencias de la Salud, Universidad Jaén, Jaén, Spain and 3 Unidad de Investigación, Hospital \\ Universitario Virgen de las Nieves, Granada, Spain \\ Email: Eva Jiménez-Medina - evajimenez@fundacionhvn.org; Enrique Berruguilla - quiquebp@hotmail.com; Irene Romero - iroga@ya.com; \\ Ignacio Algarra - ialgarra@ujaen.es; Antonia Collado - antonia.collado.sspa@juntadeandalucia.es; \\ Federico Garrido - federico.garrido.sspa@juntadeandalucia.es; Angel Garcia-Lora* - angel.miguel.exts@juntadeandalucia.es \\ * Corresponding author
}

Published: 24 March 2008

BMC Cancer 2008, 8:78 doi:10.1/86/147/-2407-8-78
Received: 5 November 2007

Accepted: 24 March 2008

This article is available from: http://www.biomedcentral.com/I47/-2407/8/78

(c) 2008 Jiménez-Medina et al; licensee BioMed Central Ltd.

This is an Open Access article distributed under the terms of the Creative Commons Attribution License (http://creativecommons.org/licenses/by/2.0), which permits unrestricted use, distribution, and reproduction in any medium, provided the original work is properly cited.

\begin{abstract}
Background: Protein-bound polysaccharide (PSK) is derived from the CM-I0I strain of the fungus Coriolus versicolor and has shown anticancer activity in vitro and in in vivo experimental models and human cancers. Several randomized clinical trials have demonstrated that PSK has great potential in adjuvant cancer therapy, with positive results in the adjuvant treatment of gastric, esophageal, colorectal, breast and lung cancers. These studies have suggested the efficacy of PSK as an immunomodulator of biological responses. The precise molecular mechanisms responsible for its biological activity have yet to be fully elucidated.
\end{abstract}

Methods: The in vitro cytotoxic anti-tumour activity of PSK has been evaluated in various tumour cell lines derived from leukaemias, melanomas, fibrosarcomas and cervix, lung, pancreas and gastric cancers. Tumour cell proliferation in vitro was measured by $\mathrm{BrdU}$ incorporation and viable cell count. Effect of PSK on human peripheral blood lymphocyte (PBL) proliferation in vitro was also analyzed. Studies of cell cycle and apoptosis were performed in PSK-treated cells.

Results: PSK showed in vitro inhibition of tumour cell proliferation as measured by BrdU incorporation and viable cell count. The inhibition ranged from 22 to $84 \%$. Inhibition mechanisms were identified as cell cycle arrest, with cell accumulation in $G_{0} / G_{1}$ phase and increase in apoptosis and caspase-3 expression. These results indicate that PSK has a direct cytotoxic activity in vitro, inhibiting tumour cell proliferation. In contrast, PSK shows a synergistic effect with IL-2 that increases PBL proliferation.

Conclusion: These results indicate that PSK has cytotoxic activity in vitro on tumour cell lines. This new cytotoxic activity of PSK on tumour cells is independent of its previously described immunomodulatory activity on NK cells. 


\section{Background}

A number of bioactive molecules, including antitumour substances, have been identified in various mushroom species. Polysaccharides are the best known and most potent of these and have antitumour and immunomodulating properties [1-5]. PSK, a protein-bound polysaccharide obtained from Basidiomycetes, also known as Krestin, has been used as an agent in the treatment of cancer in Asia for over 30 yrs [6-8]. PSK is derived from the fungus Coriolus versicolor and has documented anticancer activity in vitro in experimental models [9] and in human clinical trials. Several randomized clinical trials have demonstrated that PSK has great potential in adjuvant cancer therapy, with positive results in the treatment of gastric, esophageal, colorectal, breast and lung cancers $[10,11]$. These studies have suggested the efficacy of PSK as an immunomodulator of biological response.

Previous reports indicated that PSK might act in different ways: as antioxidant $[5,12,13]$; as inhibitor of metalloproteinases and other enzymes involved in metastatic processes [14] and as inhibitor of the action of various carcinogens in vulnerable cell lines. However its most important and widely reported property is its immunomodulatory capacity. PSK may act to increase leukocyte activation and response via upregulation of key cytokines. Thus, natural killer (NK) and lymphocyte-activated killer (LAK) cell activation has been demonstrated in vivo and in vitro $[15,16]$. Our group demonstrated that PSK is capable of inhibiting metastatic colonization in vivo in some experimental fibrosarcomas, and that this effect is mediated by activation of NK cells $[17,18]$. Moreover, the NK cell line NKL, derived from a large granular lymphocyte leukaemia [19], is activated in vitro by PSK [16]. This activation may replace IL-2 in inducing the proliferation and cytotoxicity of NKL cells. The signal transduction pathways involved in the responses to IL-2 or PSK are different: IL-2 increases PKC $\alpha$ and ERK3 expression and decreases ERK2 expression, whereas PSK decreases PKC $\alpha$ expression and increases ERK3 expression [20]. PSK also enhances CRE binding activity, while IL-2 increases SP-1 and modifies GAS/ISRE, IRF-1 and STAT5 [21]. In addition, PSK and IL-2 have been shown to bind to different receptor on NKL cells [22].

The direct in vitro effect of PSK on the proliferation of tumour cell lines was compared with its effect on PBLs. PSK had cytotoxic activity on tumour cell lines, inhibiting proliferation, producing cell cycle arrest and cell accumulation in $\mathrm{G}_{0} / \mathrm{G}_{1}$ phase and inducing apoptosis.

\section{Methods}

\section{Protein-bound polysaccharide $K$}

Protein-bound polysaccharide K (PSK) was kindly provided by Kureha Chemical Ind. Co. (Tokyo, Japan). It is prepared by extracting cultured mycelia of Coriolus versicolor with hot water. The precipitate is separated from the clear supernatant with saturated ammonium sulfate, then desalted and dried [23]. Protein-bound polysaccharide K was dissolved in RPMI medium or water and heated at $50^{\circ} \mathrm{C}$ for $20-30 \mathrm{~min}$ until a clear solution appeared. The PSK preparation was filter-sterilized and diluted in culture medium or water to the desired concentration. Proteinbound polysaccharide $\mathrm{K}$ was previously titrated in NKL cells [16] and the working dilution was $100 \mu \mathrm{g} / \mathrm{mL}$. PSK extract digested with neuraminidase was also tested, digesting $100 \mu \mathrm{g}$ of PSK with $4 \mu \mathrm{l}$ (Sigma) and incubating for $3 \mathrm{~h}$ at $37^{\circ} \mathrm{C}$. Our group previously showed that PSK is composed of two bands of very high molecular weight [22]. After digestion with neuraminidase, these bands are reduced to a single band of about $12 \mathrm{kd}$. These results indicate that PSK is probably composed of a single 12-kd protein, and that this protein is highly glycosylated [22]. Two different extracts of PSK were also used: one rich in sugars and other rich in proteins.

\section{Cell lines and cell culture}

The following tumour cell lines were studied: B16 murine melanoma, B9 murine MCA-induced fibrosarcoma, Ando-2 human melanoma, AGS human gastric cancer, A549 human lung cancer, Hela human cervical adenocarcinoma and Jurkat T lymphoma leukemia. The NKL studied was established from PBLs of a patient with LGL leukemia [19]. All cell lines were obtained from the American Type Culture Collection (Manassas, USA) except for the B9 cell line, which was generated at our laboratory, and the Ando-2 and NKL cell lines, kindly provided by P. Coulie (Unite de Genetique Cellulaire, Louvain University, Brussels, Belgium), F. X. Real (Instituto Municipal de Investigaciones Medicas, Barcelona, Spain) and Dr. M. LopetBotet (Universidad Pompeu-Fabra, Barcelona, Spain), respectively.

Cell lines derived from solid tumours were grown at $37^{\circ} \mathrm{C}$ in a humidified atmosphere of $5 \% \mathrm{CO}_{2}$ in DMEM culture medium (Gibco, Paisley UK) supplemented with 10\% heat-inactivated foetal bovine serum (Life Technologics, Milan Italy), antibiotics and glutamine. Jurkat T cell leukemia was cultured in RPMI 1640 with $10 \%$ heat-inactivated fetal bovine serum. The NKL cell line was cultured in RPMI 1640 with $10 \%$ heat-inactivated human $\mathrm{AB}$ serum (Sigma Chemical, St Louis, MO; USA) and human recombinant IL-2 $(100 \mathrm{U} / \mathrm{ml}$; purity $>97 \%$, specific activity, $2 \times 10^{6} \mathrm{U} / \mathrm{mg}$ ) (Roche, Nutley, NJ; USA).

\section{In vitro cytotoxicity assays}

The effect of PSK on tumour cell proliferation was assessed by measuring BrdU incorporation with the BrdU colorimetric ELISA Cell Proliferation Kit (Roche Diagnostic). Cells were plated in 96-well microculture plates $(5 \times$ 
$10^{3}$ cells/well). Every $48 \mathrm{~h}$, the culture medium was replaced and PSK was added. After 48-96 h, BrdU labelling reagent was added and cultured for a further 1-3 h. Assays were also performed by counting viable cells using Trypan Blue. Briefly, cancer cell lines were seeded into culture tissue-flask (1.5-2 × $10^{5}$ /culture tissue-flask) and incubated for $24 \mathrm{~h}$ at $37^{\circ} \mathrm{C}$ in a humidified atmosphere of $5 \% \mathrm{CO}_{2}$. Cells were then treated with $100 \mu \mathrm{g} / \mathrm{ml}$ of PSK in the culture medium, which was replaced every $48 \mathrm{~h}$. After 4-6 days, cells were collected by centrifugation and a small sample of cell suspension was diluted in $0.4 \%$ Trypan Blue, counting cells in a haemocytometer chamber. Each cell sample was counted in this way at least three times and each assay was repeated at least three times.

\section{Lymphocyte and NKL proliferation assay}

Human lymphocytes were isolated from venous blood by the Ficoll-Hystopaque separation method. Proliferation of PBLs was analyzed in vitro using 5-bromo-2'-deoxyuridine (BrdU) labelling of DNA-synthesizing cells with the above-mentioned kit. PBLs were seeded in 96-well microculture plates at a cell density of $5 \times 10^{4}$ per well. Two different concentrations of PSK were used, $100 \mu \mathrm{g} / \mathrm{ml}$ and 50 $\mu \mathrm{g} / \mathrm{ml}$. Concanavalin A (5 $\mu \mathrm{g} / \mathrm{ml}$, Sigma) and IL-2 were used as positive controls. PSK was also used in combination with IL-2 or Concanavalin A. After $48 \mathrm{~h}$ of culture in presence or absence of PSK, BrdU labelling reagent (final concentration $10 \mu \mathrm{M}$ ) was added and cells were cultured for $24 \mathrm{~h}$. Cells were then fixed for $30 \mathrm{~min}$ and incubated with anti-BrdU for $1 \mathrm{~h}$ at $37^{\circ} \mathrm{C}$. $100 \mu \mathrm{l}$ of tetramethyl-benzidine (TMB) was used as substrate. Optical densities were determined at $370 \mathrm{~nm}$ by means of an ELISA microplate reader (Biotek, Power-Wave XS). Controls were the culture medium, cells cultured only in medium and cells incubated with anti-BrdU in absence of BrdU. All experiments were repeated at least three times.

\section{Cell cycle distribution analysis}

Briefly, cells were plated in six-well plates $\left(5 \times 10^{5}\right.$ per well) or in culture tissue-flask $\left(15 \times 10^{5}\right)$ and continuously exposed for 4 days to $100 \mu \mathrm{g} / \mathrm{ml}$ of PSK. The DNA synthesis rate was examined by BrdU incorporation method using FITC BrdU Flow Kit (BD Pharmingen) according to manufacturer's instructions. BrdU was then detected by DNase cell treatment using FITC-conjugated anti-BrdU antibody. Cells were washed with $1 \mathrm{ml} 1 \times \mathrm{BD}$ Perm/Wash Buffer, and $20 \mu \mathrm{l} 7$-amino-actinomycin D was added. Analysis was performed with 50000 cells using Cell Quest Software and FACScan flow cytometer (BectonDickinson).

\section{Annexin V binding assay to detect apoptotic cells}

After treatment of cancer cells with PSK for four days, cells were detached from the culture tissue-flask with PBS containing $3 \mathrm{mM}$ EDTA. These cells were then collected together with floating cells, washed twice with cold PBS and resuspended in binding buffer at a concentration of 1 $\times 10^{6}$ cells per ml; $100 \mu$ l of solution was incubated for 30 min at $4^{\circ} \mathrm{C}$ with $5 \mu \mathrm{l}$ of Annexin V-PE antibody (BD Biosciences), and $5 \mu$ l of 7 -amino-actynomycin D was then added. Cells were incubated for $15 \mathrm{~min}$ in darkness, and $400 \mu \mathrm{l}$ of staining buffer was added before flow cytometry analysis. Apoptosis was analyzed by quadrant statistics as follows: Annexin V- and 7-AAD-negative cells are alive; Annexin V-positive and 7-AAD-negative cells are in early stages of apoptosis; Annexin V-negative and 7-AAD-positice cells are dead but not by apoptosis; and Annexin Vpositive and 7-AAD-positive cells are in mid- or end-stage apoptosis.

\section{Assay for active caspase-3 expression}

FITC conjugated monoclonal anti-active-caspase- 3 antibody (BD Biosciences) was used to determine whether the protease caspase-3 is involved in PSK-induced apoptosis. After 4-day treatment with PSK, cancer cells were washed twice with cold PBS and fixed and permeabilized in Cytofix/Cytoperm buffer. Then, cells were incubated with FITC-conjugated monoclonal rabbit anti-active humancaspase- 3 antibody for $30 \mathrm{~min}$. Cells were washed twice and $500 \mu \mathrm{l}$ of $1 \times$ Perm Wash Buffer was added before analysis by flow cytometry.

\section{Statistical analysis}

Values are expressed as means \pm SD. Student's $t$-test was used for statistical comparisons, considering a significance value of $\mathrm{P}<0.05$.

\section{Results \\ PSK inhibits in vitro tumour cell proliferation}

Tumour cell lines were cultured in 96-well plate for 48-72 h (2.5-5 $\times 10^{3}$ cells) in medium alone (control) or with PSK $(100 \mu \mathrm{g} / \mathrm{ml}$ or $50 \mu \mathrm{g} / \mathrm{ml})$ for 4-6 days. Cell proliferation was then measured by BrdU incorporation (absorbance), which was significantly lower in PSK-treated versus untreated tumour cells (Fig. 1). AGS and A549 cell lines showed a strong decrease in absorbance after treatment with $100 \mu \mathrm{g} / \mathrm{ml}$ PSK that was less marked after treatment with $50 \mu \mathrm{g} / \mathrm{ml}$ of PSK. Inhibition of proliferation was around 65\% in melanoma cell lines B16 and Ando-2, lower in Hela and Jurkat cell lines and lowest (20\%) in B9 murine fibrosarcoma (Fig. 1). PSK-treated tumour cells showed morphological changes (rounded and granulated morphology, increased vacuolisation, cell shrinkage) and a large number of the cells detached from culture flasks.

These assays were repeated in cell culture flasks (1.5-2.5 $\times$ $10^{5}$ cells), and viable cells were counted in Haemacytometer chamber using Trypan Blue. As shown in Table 1, there was a significant decrease in the final number of viable cells, with a proliferation inhibition of $22 \%-84 \%$ versus 


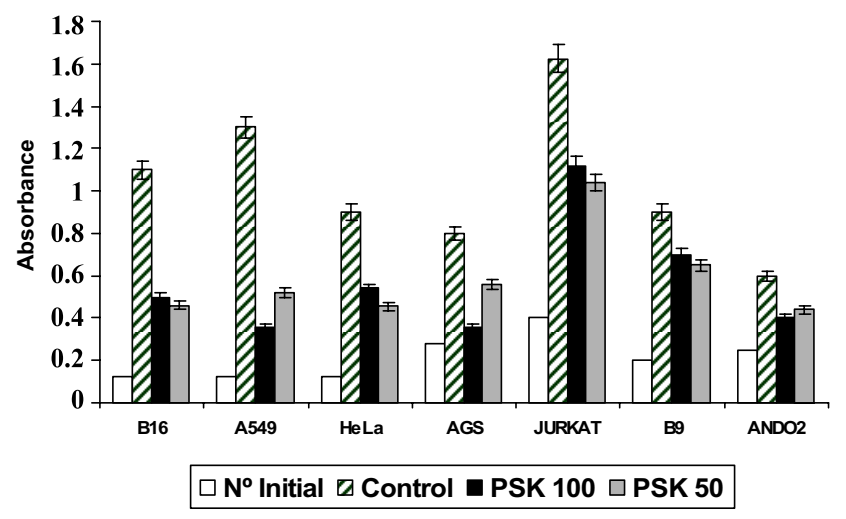

Figure I

Effect of PSK on tumour cell line proliferation. B I6, A549, Hela, AGS, Jurkat, B9 and Ando-2 tumour cell lines were treated or not with $50 \mu \mathrm{g} / \mathrm{ml}$ or $100 \mu \mathrm{g} / \mathrm{ml}$ of PSK for $72-96 \mathrm{~h}$. Tumour cells $\left(2.5\right.$ to $\left.5 \times 10^{4}\right)$ were plated in quadruplicate in 96-well plates. The proliferation of tumour cells was determined by BrdU incorporation and absorbance measurement. All cell lines analysed showed inhibition of proliferation. Each column represents the mean of five independent experiments $\pm S D$. $P<0.00$ I versus control.

control cells. There was an excellent correlation between the results obtained with the two assays (absorbance and cell count). In Hela tumour cells, proliferation inhibition was higher after treatment with $50 \mu \mathrm{g} / \mathrm{ml}$ versus $100 \mu \mathrm{g} /$ $\mathrm{ml}$ of PSK. In all other tumour cell lines, proliferation inhibition was similar or higher at $100 \mu \mathrm{g} / \mathrm{ml}$ PSK.

\section{PSK increases in vitro proliferation of IL-2-stimulated lymphocytes}

A dose-response analysis was performed to determine the in vitro effect of PSK on human PBLs. PBLs $(5 \times 104)$ were plated in 96-well tissue plate for 48-72 h with eight serially diluted extractions ranging from $500 \mu \mathrm{g} / \mathrm{ml}$ (concentration $\mathrm{n}^{\circ} 8$ ) to $3.9 \mu \mathrm{g} / \mathrm{ml}$ (concentration $\mathrm{n}^{\circ} 1$ ). Concentration $\mathrm{n}^{\circ} 0$ represents cells cultured in medium alone. BrdU incorporation during DNA synthesis was

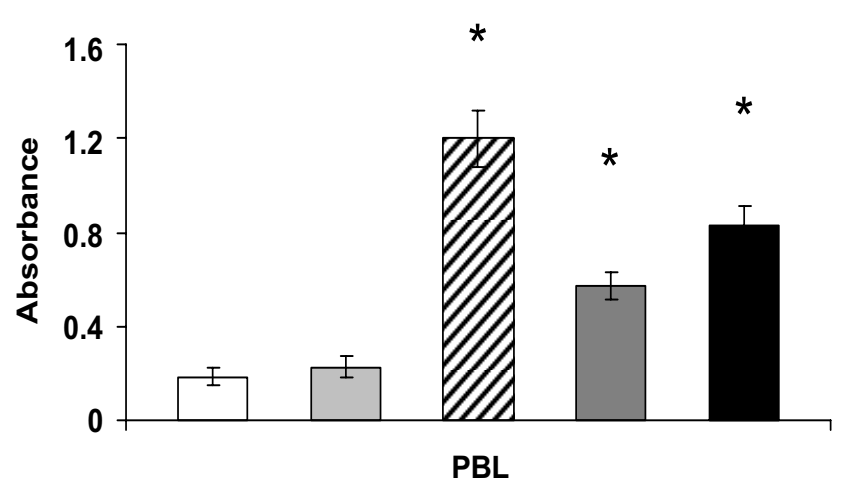

$\square$ Control $\square$ PSK $\square$ Concan. $\square$ IL-2 $\square$ PSK+IL2

Figure 2

Effect of PSK on PBL proliferation. PBLs were cultured with PSK or IL-2 or with PSK+IL-2. PBLs $\left(50 \times 10^{4}\right.$ cells $)$ were seeded in quadruplicate in 96-well plates. The proliferation was determined by $\mathrm{BrdU}$ incorporation and absorbance measurement. PSK showed a synergistic effect with IL-2, increasing PBL proliferation. PSK alone did not induce PBLs proliferation. Each column represents the mean of five independent experiments $\pm \mathrm{SD}$. $* \mathrm{P}<0.00$ I versus control.

then measured by ELISA. Optical densities were very similar between treated and untreated PBLs (data not shown). However, simultaneous treatment of PBLs with IL-2 (100 $\mathrm{U} / \mathrm{ml})+\mathrm{PSK}(100 \mu \mathrm{g} / \mathrm{ml})$ produced a higher proliferation rate (4.5-fold) versus PBLs treated with IL-2 alone (3-fold) (Fig. 2). Untreated and Concanavalin A-treated PBLs served as controls (Fig. 2).

\section{Effect of different variants of PSK}

Tumour cell proliferation inhibition was compared among different PSK variants. Neuraminidase treatment digests glicosylated proteins. A549 tumour cell line was cultured in medium alone (control) or with PSK $(100 \mu \mathrm{g} /$ $\mathrm{ml})$ or neuraminidase-treated PSK $(100 \mu \mathrm{g} / \mathrm{ml})$ for $4-6$

Table I: Proliferation of tumour cell lines treated with PSK

\begin{tabular}{|c|c|c|c|c|c|c|}
\hline \multirow[b]{2}{*}{ Tumour cell line } & \multicolumn{4}{|c|}{ Cell No. $\left(\times 10^{4}\right)$} & \multicolumn{2}{|c|}{$\%$ inhibition } \\
\hline & Initial & Control & PSKI* & PSK2* & PSKI & PSK2 \\
\hline $\mathrm{B} 16$ & 25 & $220 \pm 5$ & $100 \pm 2$ & $92 \pm 2$ & 62 & 65 \\
\hline AGS & 14 & $40 \pm 1$ & $18 \pm 1$ & $21 \pm 1$ & 84 & 71 \\
\hline Hela & 25 & $180 \pm 5$ & $108 \pm 4$ & $91 \pm 4$ & 46 & 57 \\
\hline A549 & 25 & $260 \pm 5$ & $72 \pm 2$ & $104 \pm 3$ & 80 & 56 \\
\hline Jurkat & 80 & $325 \pm 5$ & $224 \pm 3$ & $208 \pm 3$ & $4 I$ & 47 \\
\hline B9 & 20 & $90 \pm 4$ & $75 \pm 3$ & $72 \pm 3$ & 22 & 26 \\
\hline Ando-2 & 15 & $30 \pm 1$ & $20 \pm 1$ & $22 \pm 1$ & 67 & 54 \\
\hline
\end{tabular}

*PSK I: $100 \mu \mathrm{g} / \mathrm{ml}$; PSK2: $50 \mu \mathrm{g} / \mathrm{ml} . \mathrm{P}<0.001$ versus control 

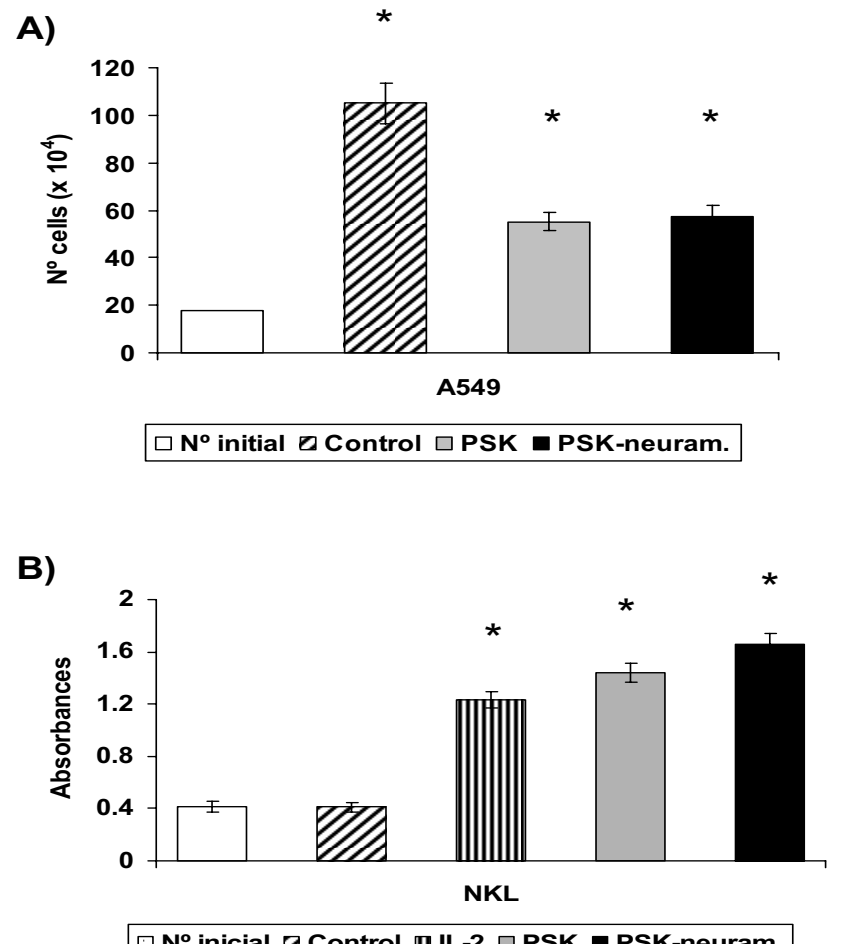

Figure 3

In vitro activity of neuraminidase treated-PSK. a) A549 tumour cell line was cultured with neuraminidasetreated PSK or PSK. A549 tumour cells $\left(20 \times 10^{4}\right)$ were seeded in culture flask and treated with PSK for $96 \mathrm{~h}$, estimating cell viability by means of Trypan blue exclusion. Both agents produced a similar inhibition ofproliferation. b) NKL cell line was cultured with PSK or neuraminidase treated-PSK and proliferation was determined by BrdU incorporation and absorbance measurement. Both agents induced a similar increase of proliferation. Each column represents the mean of five independent experiments $\pm S D$. $* P<0.001$ versus control.

days and then counted using trypan blue. No significant differences in proliferation inhibition were found between PSK and neuraminidase-treated PSK (Fig. 3a). The same results were found for sugar-rich and proteinrich PSK variants as for PSK (data not shown).

It was previously reported that PSK induces proliferation and activation of NKL cells [16]. Treatment of NKL cells with $100 \mu \mathrm{g} / \mathrm{ml}$ PSK or neuraminidase-treated PSK for 96 $\mathrm{h}$ induced a similar increase in their proliferation (Fig. $3 \mathrm{~b})$, which was slightly higher than that obtained after culture of NKL with IL-2 alone (Fig. 3b). Induction of NKL proliferation was slightly lower in sugar-rich and proteinrich PSK variants; this difference was not significant (data not shown)
Cell cycle phase distribution analysis of PSK-treated cells Mechanisms of PSK cytotoxic activity were analysed by flow cytometry in order to study the effect on cell cycle phase distribution. Culture of AGS tumour cell line with $100 \mu \mathrm{g} / \mathrm{ml}$ of PSK produced total cell cycle arrest with cell accumulation in $G_{0} / G_{1}$ phase and no cells in $S$ phase (Fig. 4). Cell cycle phase distributions were: $32.2 \% \mathrm{G}_{0} / \mathrm{G}_{1}$, $31.1 \% \mathrm{~S}$ and $16.2 \% \mathrm{G}_{2} / \mathrm{M}$ in control AGS cells and $60.8 \%$ $\mathrm{G}_{0} / \mathrm{G}_{1}, 0 \% \mathrm{~S}$ and $14.1 \% \mathrm{G}_{2} / \mathrm{M}$ in PSK-treated AGS cells. Similar results were found in Ando-2, A549 and B16 tumour cell lines (Table 2). Results in B9 fibrosarcoma showed a slowing rather than an arrest of the cell cycle (Fig.4), with a partial accumulation in $G_{0} / G_{1}$ phase (49.15\% untreated cells and $63.17 \%$ PSK-treated cells) at the expense of a decrease in $S$ phase $(20.54 \%$ vs. $15.14 \%)$ and $\mathrm{G}_{2} / \mathrm{M}$ phase $(12.6 \%$ vs. $6.96 \%)$. Similar results were found in Hela and Jurkat tumour cells (Table 2). These results indicate that PSK produces arrest or slowing of the cell cycle according to the tumour cell histology.

Analysis of apoptosis in tumour cells treated with PSK

Cancer cell lines were treated with $100 \mu \mathrm{g} / \mathrm{ml}$ PSK for 4 days to examine the capacity of PSK to induce apoptosis. Untreated or PSK-treated cancer cells were incubated with Annexin V-PE in a buffer containing 7-amino-actinomycin (7-AAD) and analyzed by flow cytometry. Figure 5 depicts representative results for AGS and B9 tumour cells. PSK increased apoptosis from $4.32 \%$ (untreated cells) to $37.52 \%$ in AGS cells but not in B9 tumour cells (untreated cells, $11.37 \%$ vs. PSK-treated cells, $12.11 \%)$. Table 3 depicts the results for other tumour cell lines, showing that PSK induces apoptosis in A549, B16 and Ando-2 tumour cells.

Table 2: Effect of PSK on cell cycle distribution of tumor cell lines.

\begin{tabular}{lrrrr}
\hline Tumour cell line & \multicolumn{4}{c}{ Cell cycle distribution (\%) } \\
\cline { 2 - 5 } & SUB-G I & G2 & S & G I \\
\hline AGS control & 5.12 & 16.20 & 31.10 & 32.20 \\
AGS PSK & 12.23 & 14.10 & 0 & 60.80 \\
Ando-2 & 6.35 & 18.12 & 32.25 & 33.46 \\
Ando-2 PSK & 12.40 & 16.30 & 4.35 & 60.10 \\
A549 control & 7.25 & 15.53 & 31.15 & 30.67 \\
A549 PSK & 11.95 & 13.13 & 5.20 & 49.45 \\
BI6 control & 8.35 & 12.25 & 30.23 & 31.45 \\
B16 PSK & 14.35 & 8.35 & 5.45 & 55.67 \\
Jurkat control & 8.23 & 18.60 & 32.35 & 25.50 \\
Jurkat PSK & 11.30 & 18.35 & 15.25 & 45.35 \\
HELA control & 5.58 & 16.35 & 21.12 & 44.67 \\
HELA PSK & 10.57 & 9.56 & 14.78 & 51.56 \\
B9 & 5.20 & 12.60 & 20.54 & 49.15 \\
B9 PSK & 6.56 & 6.96 & 15.14 & 63.17 \\
\hline
\end{tabular}

Results are for one typical experiment out of three performed. 

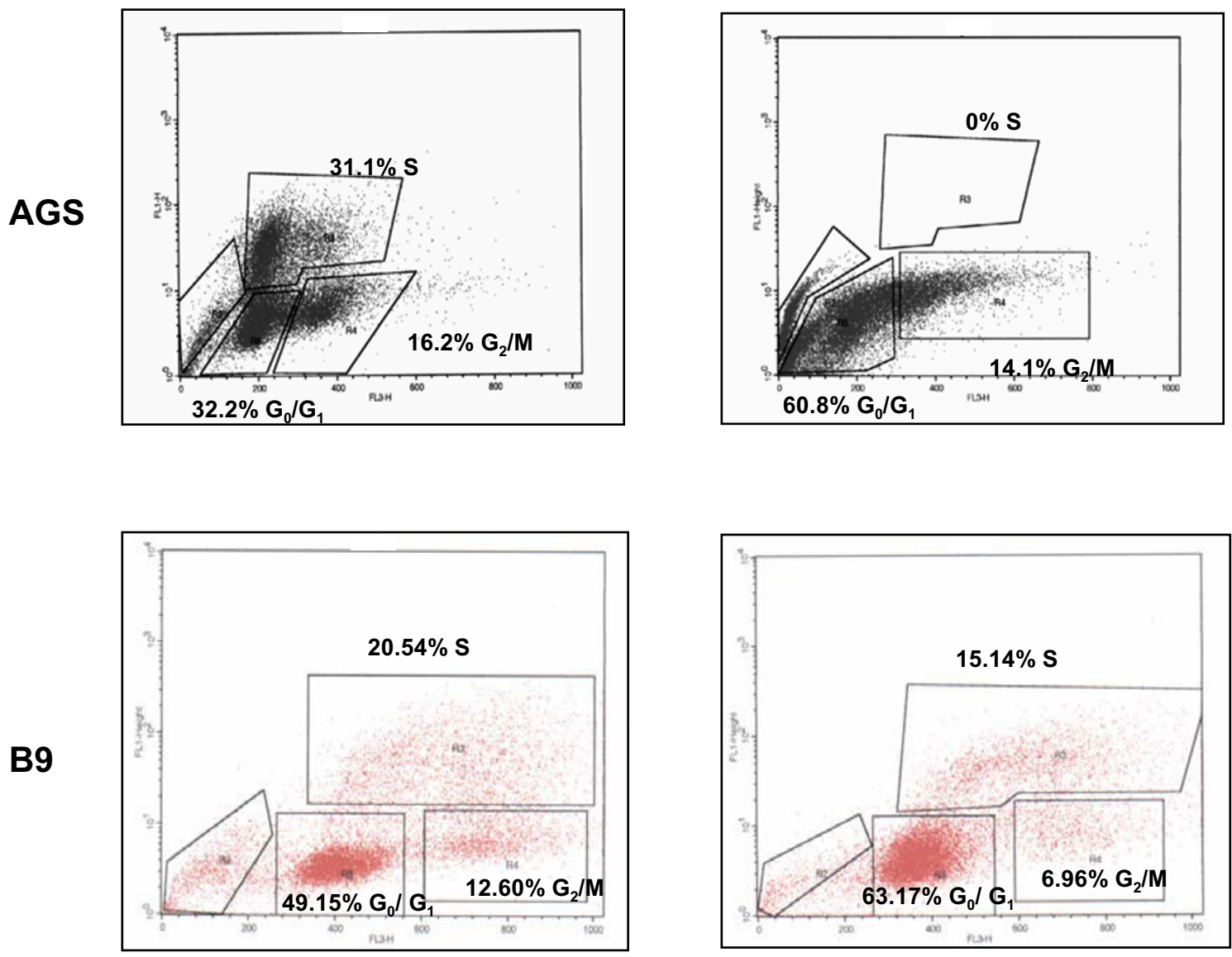

Control

PSK

Figure 4

Cell cycle analysis of cells treated with PSK. Tumour cell lines were treated with PSK for $96 \mathrm{~h}$. Cell cycle distribution was determined by flow cytometry using BrdU incorporation and 7-AAD. Data indicate the percentage of cells in each phase of cell cycle. Results are representative of three independent experiments.

\section{Expression of active human caspase-3}

Caspases are the main enzymes involved in the apoptotic pathway and the participation of active caspase-3 in PSKinduced apoptosis was evaluated. Tumour cells were treated with PSK $(100 \mu \mathrm{g} / \mathrm{ml})$ for 4 days, then permeabilized, fixed and stained for active human caspase- 3 and analyzed by flow cytometry. In the AGS cell line, untreated cells were negative for presence of active-caspase-3, whereas around $36 \%$ of PSK-treated cells showed detectable active caspase-3 (Fig. 6). However, in tumour cell lines in which PSK did not produce apoptosis, e.g., B9 tumour cells, no caspase- 3 expression was detected after PSK treatment (Fig. 6). Table 4 depicts the results obtained with the other tumour cell lines analysed.

\section{Discussion}

Several clinical assays have reported the anti-tumour properties of PSK and its synergestic effect in combined therapies $[9,24,25]$. Our group previously reported the immunomodulatory activity of PSK on NK cells, producing in vitro proliferation and activation of NKL cells $[16,20,21]$. In the present study, we have identified a new cytotoxic anti-tumour activity of PSK. This activity varied according to the histological origin of the tumour cell lines under study, with inhibition rates ranging from $84 \%$ to $22 \%$ (Table 1 ). The highest profileration inhibition rates were found in AGS (84\%) and A549 (80\%) cell lines (gastric and lung cancer, respectively). PSK was previously reported to be effective in adjuvant immunotherapy for patients after curative resection of gastric cancer [25], and this effect was attributed to its immunomodulatory activity on NK cells [26]. Our group previously reported that 

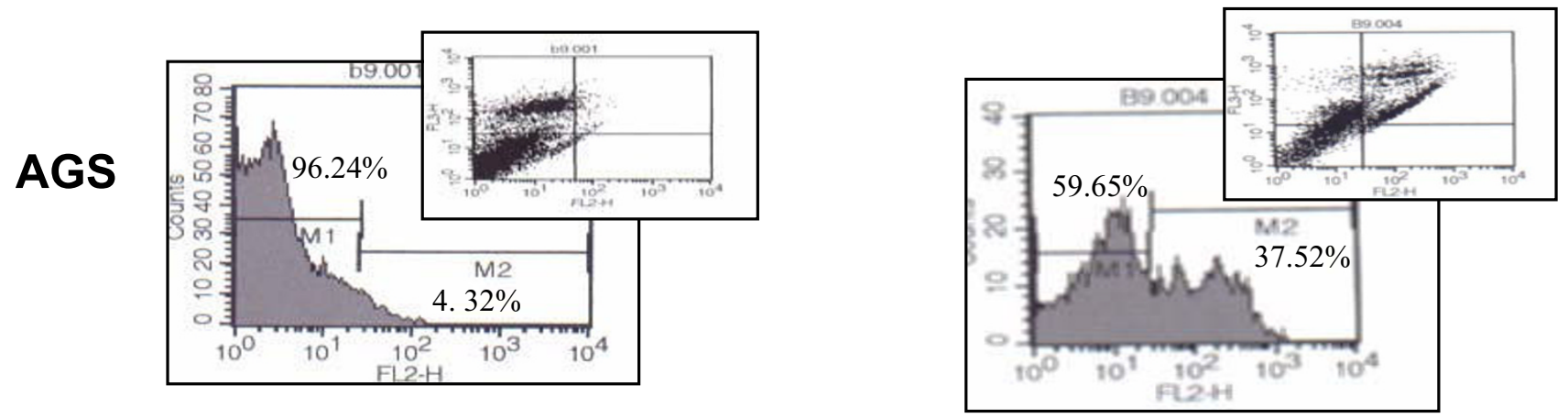

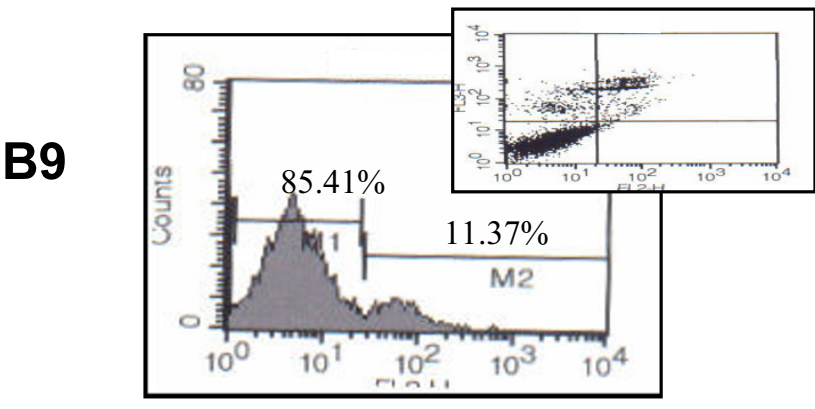

Control

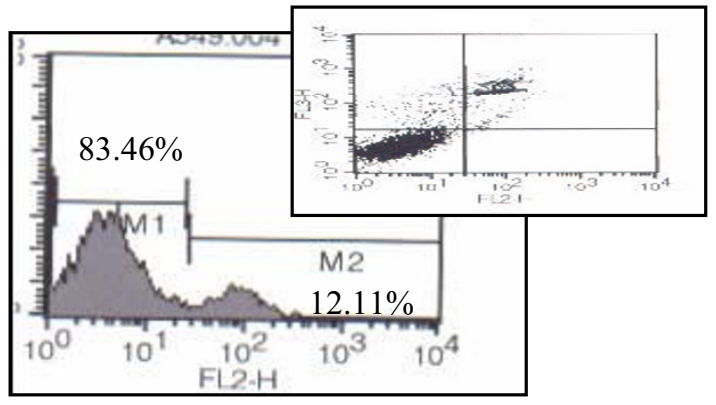

PSK

\section{Figure 5}

Apoptosis analysis of cells treated with PSK. AGS cell line was untreated or treated with $50 \mu \mathrm{g} / \mathrm{ml}$ of PSK for $96 \mathrm{~h}$. Cells were double-stained with annexin $\mathrm{V}$ and 7AAD and analyzed by flow cytometry. PSK produced apoptosis in AGS tumour cell line. B9 tumour cell line was also cultured with PSK but apoptosis was not detected in this tumour cell line. All experiments were performed at least three times and gave similar results.

Table 3: Apoptosis induction in cancer cell lines after treatment with PSK for 4 days.

\begin{tabular}{lrc}
\hline Tumour cell line & \multicolumn{2}{c}{ Apoptosis (\%) } \\
\cline { 2 - 3 } & Control & PSK $100 \mu \mathbf{g} / \mathbf{m l}$ \\
\hline AGS & $4.32 \%$ & $37.52 \%$ \\
A549 & $10.40 \%$ & $35.50 \%$ \\
B16 & $8.90 \%$ & $25.40 \%$ \\
Ando-2 & $7.98 \%$ & $18.35 \%$ \\
JURKAT & $6.10 \%$ & $10.71 \%$ \\
HELA & $9.35 \%$ & $14.30 \%$ \\
B9 & $11.37 \%$ & $12.11 \%$ \\
\hline
\end{tabular}

This assay was repeated at least three times, producing similar results.
PSK mediates induction of the NKL cell proliferation and activation. The present results suggest that PSK may also exert a direct antitumour cytotoxic activity. Inhibition was around 65\% in melanoma cell lines Ando-2 (human) and B16 (mice) and was lowest (22\%) in the B9 murine fibrosarcoma cell line. Deglycosylation of PSK by neuraminidase treatment did not modify its cytotoxic effect on tumour cell lines. The sugar-rich and protein-rich PSK variants showed identical results to those of PSK in their inhibition of proliferation of tumour cell lines in vitro. These results indicate that the cytotoxic properties are in a compound that is present in all three variants studied and does not vary among them.

Interestingly, PSK had the opposite effect on lymphocytes. Thus, PSK, in synergy with IL-2, induced proliferation of 

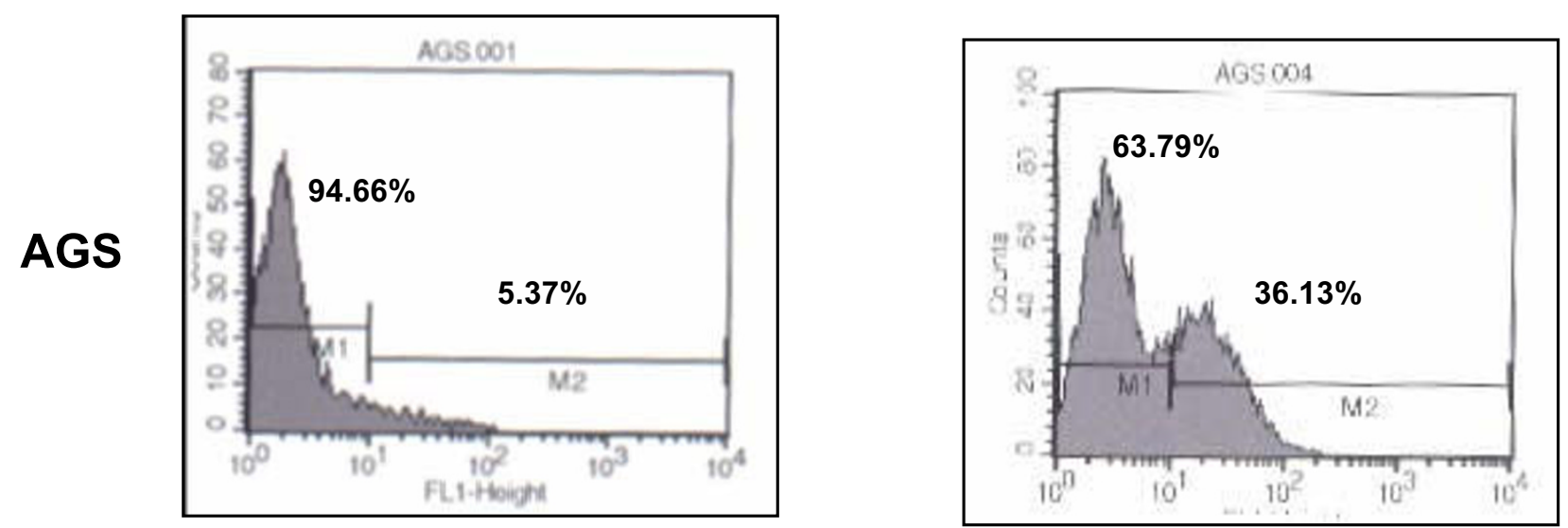

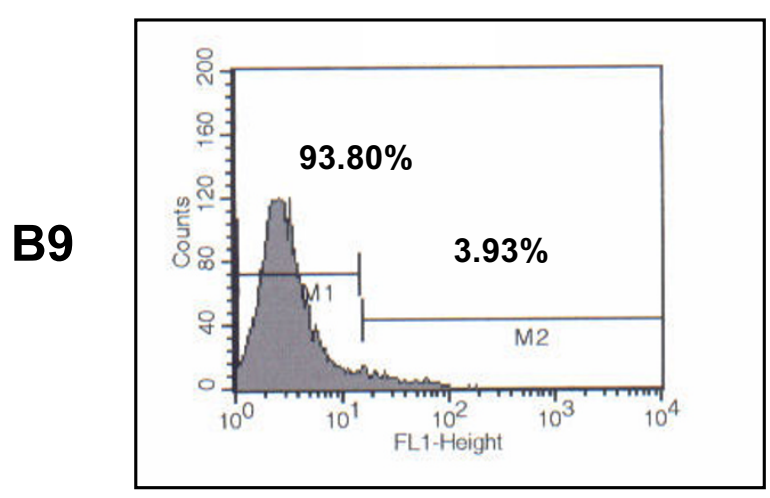

Control

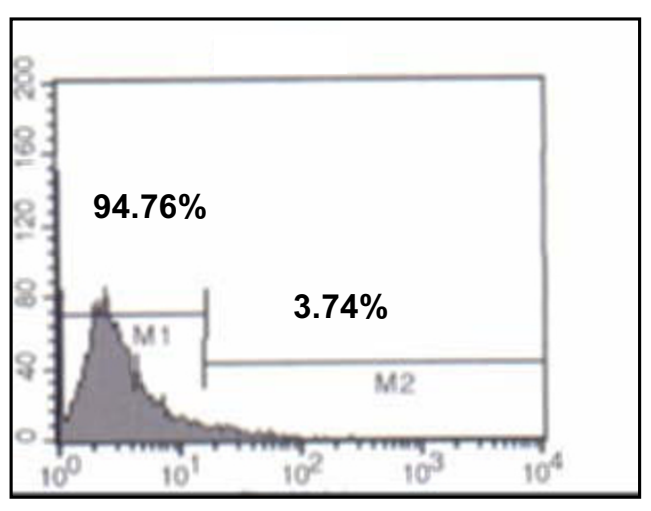

PSK

\section{Figure 6}

Caspase-3 expression in tumour cell lines treatedwith PSK. AGS and B9 tumour cell lines were treated with $50 \mu \mathrm{g} / \mathrm{ml}$ of PSK and expression was analysed by flow cytometry using FITC conjugated monoclonal anti-active-caspase-3 antibody. Data indicate the percentage of cells positive for presence of active-caspase-3. PSK produced increased caspase-3 expression in AGS but not in B9 tumour cell lines. Results are representative of three experiments.

Table 4: Expression of caspase-3 in cancer cell lines after treatment with PSK for 4 days.

\begin{tabular}{lcr}
\hline Tumour cell line & \multicolumn{2}{c}{ Expression (\%) } \\
\cline { 2 - 3 } & Control & PSK $100 \mu \mathbf{g} / \mathbf{m l}$ \\
\hline AGS & $5.37 \%$ & $36.13 \%$ \\
A549 & $4.20 \%$ & $31.14 \%$ \\
BI6 & $6.80 \%$ & $23.35 \%$ \\
Ando-2 & $5.40 \%$ & $15.55 \%$ \\
JURKAT & $5.35 \%$ & $6.45 \%$ \\
HELA & $6.50 \%$ & $6.15 \%$ \\
B9 & $3.93 \%$ & $3.74 \%$ \\
\hline
\end{tabular}

This assay was repeated at least three times, producing similar results
PBLs. PSK also induced proliferation and activation of NKL cells, producing an effect similar to that of IL-2. Hence, PSK has a cytotoxic effect on tumour cells and a mitotic effect on lymphocytes and NK cells.

The cell cycle was arrested or slowed by PSK according to the histological origin of the tumour cells. PSK is known to increase docetaxel-induced apoptosis of NOR-P human pancreatic cancer cells [27] and of Namalwa Burkitt lymphoma cells [28]. PSK induced apoptosis in the AGS cell line but not in all tumour cell lines analysed and induced caspase-3 expression in some tumour cell lines but not all. These results indicate that PSK may induce cytotoxic activity by different molecular mechanisms according to the histology of tumour. 
The molecular mechanisms implicated in PSK-induced proliferation and activation of NKL cells have been widely described, showing that PSK and IL-2 bind to different receptors on NKL cells and induce different signal transduction pathways [20-22]. The present results indicate that the anti-tumour properties of PSK observed in clinical trials might be due to a dual biological activity: 1) a direct cytotoxic activity on tumour cells and 2) an immunomodulatory activity largely produced by NK cell activation. A similar dual activity has also been described in a Calendula extract, LACE, which produces an in vitro cytotoxic activity and in vivo immunomodulatory effect on tumour cell lines, including human and mouse melanioma cells, increasing the number and activation of CD4+, CD19+ and NKT cells [29]. PSK suppressed in vivo metastases in spontaneous metastasis assays of mouse fibrosarcoma, melanoma, rat hepatoma AH60C and mouse colon cancer $26[17,30,31]$ via NK cell activation. Based on the present findings, it can be hypothesised that this anti-metastatic capacity may also derive from the cytotoxic component of PSK.

Research into the biological mechanisms underlying the anti-tumour effect of PSK is ongoing. We can now add a direct cytotoxic effect on tumour cells to the previously described immunomodulatory effect of this polysaccharide. Greater knowledge of the molecular mechanisms implicated in PSK anti-tumour activity may improve cancer immunotherapy, leading to the application of new anti-tumour protocols.

\section{Conclusion}

PSK shows in vitro growth inhibition of various tumour cell lines, producing cell cycle arrest/slowing, apoptosis and induction of caspase-3 expression. In combination with IL-2, PSK induces proliferation of PBLs. The biological activity of PSK appears to include both an immunomodulatory effect on NK cells and a cytotoxic effect on tumour cells

\section{Abbreviations}

PBLs: Peripheral Blood Lymphocytes; LACE: laser-activated calendula extract; 7-AAD: 7-amino-actinomicin D; BrdU: 5-Bromo-2-deoxyuridine; Concan.: Concanavalin A; LAK: lymphocyte-activated killer; NK: Natural killer; TMB: tetramethyl-benzidine.

\section{Competing interests}

Materials for these studies were partially supported by a grant from Kureha Chemical Industry (Japan), which manufactures PSK. The authors declare that they have no other competing interest.

\section{Authors' contributions}

EJM, EB and IR performed the assays. IA and AC helped in some experiments. FG and AGL designed the study and drafted the manuscript. All authors have read and approved the final manuscript.

\section{Acknowledgements}

The authors thank I. Linares for technical assistance. AGL was supported by FIS Postdoctoral Research Contract CP03/00 I I I. Studies were partially supported by a grant from Kureha Chemical Industry (Japan).

\section{References}

I. Zaidman BZ, Yassin M, Mahajna J, Wasser SP: Medicinal mushroom modulators of molecular targets as cancer therapeutics. Appl Microbiol Biotechnol 2005, 67:453-468.

2. Cui J, Chisti Y: Polysaccharopeptides of Coriolus versicolor: physiological activity, uses, and production. Biotechnol Adv 2003, 2 I : I09-122.

3. Wasser SP: Medicinal mushrooms as a source of antitumor and immunomodulating polysaccharides. Appl Microbiol Biotechnol 2002, 60:258-274.

4. Pelley RP, Strickland FM: Plants, polysaccharides, and the treatment and prevention of neoplasia. Crit Rev Oncog 2000, I l: | $89-225$.

5. Ooi VE, Liu F: Immunomodulation and anti-cancer activity of polysaccharide-protein complexes. Curr Med Chem 2000, 7:715-729.

6. Nakazato $H$, Koike A, Saji S, Ogawa N, Sakamoto J: Efficacy of immunochemotherapy as adjuvant treatment after curative resection of gastric cancer. Lancet 1994, 343: I I 22.

7. Munemoto $Y$, lida $Y$, Ohata K, Saito H, Fujisawa K, Kasahara $Y$, Mitsui T, Asada Y, Miura S: Significance of postoperative adjuvant immunochemotherapy after curative resection of colorectal cancers: identification of responders incorporating the age factor. Oncol Rep 2004, I I:623-635.

8. Ohwada S, Ikeya T, Yokomori T, Kusaba T, Roppongi T, Takahashi T, Nakamura S, Kakinuma S, Iwazaki S, Ishikawa H, Kawate S, Nakajima $\mathrm{T}$, Morishita $\mathrm{Y}$ : Adjuvant immunochemotherapy with oral Tegafur/Uracil plus PSK in patients with stage II or III colorectal cancer: a randomised controlled study. Br J Cancer 2004, 90:1003-1010.

9. Katoh R, Ooshiro M: Enhancement of Antitumor Effect of Tegafur/Uracil (UFT) plus Leucovorin by Combined Treatment with Protein-Bound Polysaccharide, PSK, in Mouse Models. Cell Mol Immunol 2007, 4:295-299.

10. Sakamoto J, Morita S, Oba K, Matsui T, Kobayashi M, Nakazato H, Ohashi Y: Meta-Analysis Group of the Japanese Society for Cancer of the Colon Rectum. Efficacy of adjuvant immunochemotherapy with polysaccharide $\mathbf{K}$ for patients with curatively resected colorectal cancer: a meta-analysis of centrally randomized controlled clinical trials. Cancer Immunol Immunother 2006, 55:404-4II.

II. Ueda Y, Fujimura T, Kinami S, Hirono Y, Yamaguchi A, Naitoh H, Tani T, Kaji M, Yamagishi H, Miwa K, Hokuriku-Kinki : ImmunochemoTherapy Study Group-Gastric Cancer (HKIT-GC). A randomized phase III trial of postoperative adjuvant therapy with S-I alone versus S-I plus PSK for stage II/IIIA gastric cancer. Jpn J Clin Oncol 2006, 36:519-522.

12. Liu F, Ooi VE, Chang ST: Free radical scavenging activities of mushroom polysaccharide extracts. Life Sci 1997, 60:763-77I.

13. Asai K, Kato H, Hirose K, Akaogi K, Kimura S, Mukai S, Inoue M, Yamamura Y, Sano H, Sugino S, Yoshikawa T, Kondo M: PSK and OK-432-induced immunomodulation of inducible nitric oxide (NO) synthase gene expression in mouse peritoneal polymorphonuclear leukocytes and NO-mediated cytotoxicity. Immunopharmacol Immunotoxicol 2000, 22:22 I-235.

14. Fisher $M$, Yang $L X$ : Anticancer effects and mechanisms of polysaccharide-K (PSK): implications of cancer immunotherapy. Anticancer Res 2002, 22:1737-1754.

15. Kariya Y, Inoue N, Kihara T, Fujii M: Activation of human natural killer cells by the protein bound polysaccharide PSK inde- 
pendently of interferon and interleukin 2. Immunol Lett 1992 , 3I:24I-245.

16. Pedrinaci S, Algarra I, Garrido F: Protein-bound polysaccharide (PSK) induces cytotoxic activity in the NKL human natural killer cell line. Int J Clin Lab Res 1999, 29: I35-I40.

17. Algarra I, Collado A, Garrido F: Protein-bound polysaccharide PSK abrogates more efficiently experimental metastases derived from $\mathbf{H}-2$ negative than from $\mathbf{H - 2}$ positive fibrosarcoma tumor clones. J Exp Clin Cancer Res 1997, I6:373-380.

18. Algarra I, Garcia-Lora A, Collado A, Garrido F: Differential effect of protein-bound polysaccharide (PSK) on survival of experimental murine tumors. J Exp Clin Cancer Res 1999, 18:39-46.

19. Robertson MJ, Cochran KJ, Cameron C, Le JM, Tantravahi R, Ritz J: Characterization of a cell line, NKL, derived from an aggressive human natural killer cell leukemia. Exp Hematol 1996, 24:406-4I5

20. Garcia-Lora A, Martinez M, Pedrinaci S, Garrido F: Different regulation of PKC isoenzymes and MAPK by PSK and IL-2 in the proliferative and cytotoxic activities of the NKL human natural killer cell line. Cancer Immunol Immunother 2003, 52:59-64.

21. Garcia-Lora A, Pedrinaci S, Garrido F: Protein-bound polysaccharide $K$ and interleukin-2 regulate different nuclear transcription factors in the NKL human natural killer cell line. Cancer Immunol Immunother 200I, 50:191-198.

22. Jimenez E, Garcia-Lora A, Martinez M, Garrido F: Identification of the protein components of protein-bound polysaccharide (PSK) that interact with NKL cells. Cancer Immunol Immunother 2005, 54:395-399.

23. tsukagoshi S, hashimoto Y, Fujii G, Kobayashi H, Nomoto K, Orita K: Krestin (PSK). Cancer treatment reviews 1984, I I:I3I-I55.

24. Choi JH, Kim YB, Lim HY, Park JS, Kim HC, Cho YK, Han SW, Kim $\mathrm{MW}$, Joo $\mathrm{HJ}$ : 5-fluorouracil, mitomycin-C, and polysaccharide$K$ adjuvant chemoimmunotherapy for locally advanced gastric cancer: the prognostic significance of frequent perineural invasion. Hepatogastroenterology 2007, 54:290-297.

25. Oba K, Teramukai S, Kobayashi M, Matsui T, Kodera Y, Sakamoto J: Efficacy of adjuvant immunochemotherapy with polysaccharide $\mathrm{K}$ for patients with curative resections of gastric cancer. Cancer Immunol Immunother 2007, 56:905-9II.

26. Ohwada S, Ogawa T, Makita F, Tanahashi Y, Ohya T, Tomizawa N, Satoh Y, Kobayashi I, Izumi M, Takeyoshi I, Hamada K, Minaguchi S, Togo Y, Toshihiko T, Koyama T, Kamio M: Beneficial effects of protein-bound polysaccharide $K$ plus tegafur/uracil in patients with stage II or III colorectal cancer: analysis of immunological parameters. Oncol Rep 2006, I5(4):86I-868.

27. Zhang H, Morisaki T, Nakahara C, Matsunaga H, Sato N, Nagumo F, Tadano J, Katano M: PSK-mediated NF-kappaB inhibition augments docetaxel-induced apoptosis in human pancreatic cancer cells NOR-P I. Oncogene 2003, 22:2088-2096.

28. Hattori TS, Komatsu N, Shichijo S, Itoh K: Protein-bound polysaccharide $K$ induced apoptosis of the human Burkitt lymphoma cell line, Namalwa. Biomed Pharmacother 2004, 58:226-230.

29. Jimenez-Medina E, Garcia-Lora A, Paco L, Algarra I, Collado A, Garrido $\mathrm{F}$ : A new extract of the plant Calendula officinalis produces a dual in vitro effect: cytotoxic anti-tumor activity and lymphocyte activation. BMC Cancer 2006, 6:119.

30. Kobayashi H, Matsunaga K, Oguchi $Y$ : Antimetastatic effects of PSK (Krestin), a protein-bound polysaccharide obtained from basidiomycetes: an overview. Cancer Epidemiol Biomarkers Prev 1995, 4:275-28I.

31. Matsunaga K, Ohhara M, Oguchi Y, lijima H, Kobayashi H: Antimetastatic effect of PSK, a protein-bound polysaccharide, against the BI6-BL6 mouse melanoma. Invasion Metastasis 1996, 16:27-38.

\section{Pre-publication history}

The pre-publication history for this paper can be accessed here:

http://www.biomedcentral.com/1471-2407/8/78/prepub
Publish with Biomed Central and every scientist can read your work free of charge

"BioMed Central will be the most significant development for disseminating the results of biomedical research in our lifetime. "

Sir Paul Nurse, Cancer Research UK

Your research papers will be:

- available free of charge to the entire biomedical community

- peer reviewed and published immediately upon acceptance

- cited in PubMed and archived on PubMed Central

- yours - you keep the copyright
Biomedcentral 